\title{
EVALUATION OF A NOVEL ADJUVANT FOR USE WITH GLYPHOSATE ON PERENNIAL RYEGRASS
}

\author{
R.J. MURRAY ${ }^{1}$, R.E. GASKIN ${ }^{1}$ and M.R. GRASSAM ${ }^{2}$ \\ ${ }^{1}$ Forest Research, Private Bag 3020, Rotorua \\ ${ }^{2}$ Plant Protection Research Unit, Lincoln Ventures, PO Box 84, Canterbury
}

\begin{abstract}
Glyphosate is used extensively for pasture renovation, with an organosilicone surfactant when treating ryegrass (Lolium perenne). The effect of a novel, non-silicone surfactant, Browndown Adjuvant, on the performance of glyphosate on perennial ryegrass was determined and compared to the organosilicone surfactant, Pulse. Spray retention, uptake and translocation of glyphosate were quantified. Comparative efficacy of spray treatments was determined in pot and field trials. Browndown increased the speed and quantity of glyphosate uptake, with no adverse effects on herbicide translocation. At the recommended rate $(0.25 \% \mathrm{v} / \mathrm{v})$, Browndown reduced spray retention compared to Pulse $(0.1 \% \mathrm{v} / \mathrm{v})$, but provided faster brown-out of foliage and equivalent herbicide efficacy on glyphosate-tolerant ryegrass in spring.

Keywords: adjuvant, glyphosate, ryegrass, spray retention, spray efficacy.
\end{abstract}

\section{INTRODUCTION}

Glyphosate is used extensively for pasture renovation, to control existing pasture species prior to the establishment of new pasture or crops. The use of an organosilicone surfactant is considered essential at all times when treating ryegrass (Lolium perenne), but is especially necessary to overcome the spring tolerance of this species to glyphosate (Bishop and Field 1987).

Browndown Adjuvant is a newly developed product designed to "enhance the spread, uptake, translocation and rainfastness of certain herbicides, including glyphosate, on marginally controlled weeds" (Foot 1997). It contains 36 g/litre oxyfluorfen plus activators and penetrating additives in the form of an emulsifiable concentrate. Browndown has shown excellent activity with glyphosate on many grass and broadleaf weeds, generally speeding up initial brown-out of foliage with no deleterious effects on long-term control (Foot 1997). Such effects, plus improved rainfastening, suggest the adjuvant is improving the rate of glyphosate uptake into foliage without adversely affecting systemic movement of the active ingredient (a.i.). This study was undertaken to determine how Browndown may be contributing to improved glyphosate efficacy on perennial ryegrass and to compare its performance with that of the organosilicone surfactant, Pulse.

\section{Plants}

\section{MATERIALS AND METHODS}

For uptake and translocation studies, perennial ryegrass (cv. Concord) was grown from seed in individual pots (Bloom potting mix; Yates Ltd) and raised to 3 weeks of age under controlled environment conditions $\left(20^{\circ} \mathrm{C}\right.$ day $/ 15^{\circ} \mathrm{C}$ night; $12 \mathrm{~h}$ photoperiod). For retention and efficacy studies, individual potted ryegrass plants were germinated in the glasshouse and then placed outside to weather-harden. Plants were approximately 8 weeks old when sprayed, ie. $>6$ tillers, $20-30 \mathrm{~cm}$ leaf length, no flower initiation; Zadoks stage 30 .

\section{Chemicals}

Glyphosate (Glyphosate 360; Nufarm) was prepared at the rate of $1.08 \mathrm{~kg} / 200$ litres water for uptake and translocation studies. Radiolabelled glyphosate was added 
just prior to use at $<0.1 \%$ of the total glyphosate mass. Browndown Adjuvant (Elliott Chemicals) was added to herbicide solutions at 0.25 and $0.5 \% \mathrm{v} / \mathrm{v}$. For retention and efficacy studies, glyphosate was prepared at the sub-lethal rate of $0.72 \mathrm{~kg} / \mathrm{ha}$. Pulse (Monsanto) was added to the herbicide spray at the recommended rate of $0.1 \% \mathrm{v} / \mathrm{v}$, and Browndown at 0.25 and $0.5 \% \mathrm{v} / \mathrm{v}$. Tartrazine dye $(10 \mathrm{~g} / \mathrm{litre})$ was incorporated into all treatments. In the field trial, glyphosate (Roundup; Monsanto) was applied at $1.08 \mathrm{~kg} /$ ha with the addition of either Pulse $(0.1 \% \mathrm{v} / \mathrm{v})$ or Browndown $(0.25 \% \mathrm{v} / \mathrm{v})$.

\section{Uptake and translocation}

Ten droplets $(0.24 \mu \mathrm{l})$ of spray solution containing radiolabelled herbicide were applied to the adaxial surface of single leaves on five separate ryegrass plants. At 10 mins, 4, 24 and 48 hours after treatment (HAT), treated leaves were excised from plants and washed, and uptake was calculated as a percentage of the applied dose (Gaskin 1995). Washed foliage was combusted in a Harvey OX 300 Biological Oxidiser to determine the amount of radiolabel remaining in the treated tissue. The amount of herbicide translocated out of the treated area was determined by difference and expressed as a percentage of both applied and absorbed herbicide.

\section{Pot trial retention and efficacy}

Treatments were applied at 200 litres/ha using a calibrated, moving-belt tracksprayer. An even flat-fan spray nozzle (TeeJet 8002EVS; Spraying Systems NZ) was operated at $234 \mathrm{kPa}$, mounted $500 \mathrm{~mm}$ above ryegrass plants to simulate groundbased application for broadcast conservation tillage. Application rates were determined by spraying over plastic disks $\left(10 \mathrm{~cm}^{2} ; 4\right.$ replicates per treatment) positioned at pot height and interspersed randomly amongst replicate plants.

Plants for retention studies (20 replicate plants per treatment) were cut off at ground level immediately after spraying and foliage was washed thoroughly in $500 \mathrm{ml}$ water. Disk traps were washed in $100 \mathrm{ml}$ water. Absorbance of each sample was measured using a Pye Unicam UV/VIS spectrophotometer (tartrazine $\lambda=427 \mathrm{~nm}$ ), to determine total dye recovery. Dry weights (DW) of all individual plants were recorded. Leaf surface areas of fresh ryegrass plants (20 replicates) were measured at harvest using image analysis (V for Windows). Plants were dried subsequently and areas of treated plants (upper+lower leaf surfaces) were correlated with DW. Retention was calculated per unit weight $(\mu \mathrm{l} / \mathrm{g} D W)$, per area $\left(\mu \mathrm{g} / \mathrm{cm}^{2}\right)$, and expressed as a percentage of maximum possible spray deposition where:

$$
\text { Retention }(\%)=\frac{\left(\mu \mathrm{g} \mathrm{dye} / \mathrm{cm}^{2}\right) * 100}{\left(\mu \mathrm{g} \text { dye } / \mathrm{cm}^{2} \text { reference target }\right)}
$$

Plants for efficacy studies (15 replicates per treatment) were placed in the glasshouse for 48 HAT, then moved outside and watered daily. They were examined regularly for brown-out up to 21 days after treatment (DAT), when symptoms had developed fully. At this stage, plants were cut off at ground level and the DW of each plant determined as before. Efficacy was calculated as percent reduction in growth compared to untreated control.

\section{Field trial efficacy}

Field trials were undertaken on $5 \mathrm{~m}^{2}$ plots (four replicates) of winter-sown perennial ryegrass (cv. Moata) at Lincoln University, Canterbury. Plots were sprayed just on tillering (8 October 1997). Treatments were applied using a $\mathrm{CO}_{2}$ pressurised boom plot sprayer (200 kPa) delivering 200 litres/ha through XR11003VS nozzles. Water was sprayed as an untreated control. Five assessments of plots were made; two days prior to, and 7,21,35 and 56 DAT. The first and last two assessments determined the number of plants $/ \mathrm{m}^{2}$ within each plot (5 random $0.2 \mathrm{~m}^{2}$ quadrats/plot). The second and third assessments scored percent brown-out.

\section{Statistical analyses}

Experiments were analysed as a factorial design and analysis of variance and least significant difference (LSD) tests were used to compare treatments. Stabilising transformations were performed where necessary prior to analysis. 


\section{RESULTS AND DISCUSSION}

Glyphosate penetration into ryegrass was substantial without adjuvants (Table 1), but addition of Browndown increased both speed and total amount of herbicide uptake, particularly at the higher concentration. Rapid entry of herbicides into leaves can reduce the adverse effects of post-spray rainfall (Field and Bishop 1988) and both Browndown concentrations provided better rainfastening within 4 HAT, significantly so at the higher concentration (Table 1).

TABLE 1: Glyphosate uptake into ryegrass foliage \pm adjuvant at varying times after treatment.

\begin{tabular}{lcccl}
\hline Treatment & \multicolumn{3}{c}{ Uptake (\% of applied) } \\
& $10 \mathrm{mins}$ & $4 \mathrm{~h}$ & $24 \mathrm{~h}$ & $48 \mathrm{~h}$ \\
\hline glyphosate (1.08 kg/200 litres) & $7 \mathrm{e}$ & $69 \mathrm{~d}$ & $81 \mathrm{bc}$ & $76 \mathrm{~cd}$ \\
+ Browndown $0.25 \%$ & $7 \mathrm{e}$ & $79 \mathrm{~cd}$ & $93 \mathrm{ab}$ & $95 \mathrm{a}$ \\
+ Browndown $0.5 \%$ & $2 \mathrm{e}$ & $84 \mathrm{abc}$ & $95 \mathrm{a}$ & $96 \mathrm{a}$ \\
\hline
\end{tabular}

Means sharing common postscripts are not significantly different (LSD; $\mathrm{P}=0.05$ )

Adjuvant-induced disruption of the physiological processes of trans-laminar transfer and phloem translocation of active ingredient is well documented (Gaskin and Zabkiewicz 1988; Field et al. 1995) and is known to reduce the systemic movement of glyphosate (Gaskin and Murray 1988). In this study, adjuvant treatments had no significant effect on the proportion of absorbed herbicide which translocated within the plant (Table 2), suggesting Browndown has no phytotoxic effects on key transport processes. Translocation of applied herbicide reflected surfactant-induced enhancement of uptake; Browndown tended to increase the herbicide mass moving to active sinks (Table 2).

\section{TABLE 2: Translocation of glyphosate in ryegrass foliage \pm adjuvant ( 24 hours after treatment).}

Treatment

Translocation $(\%)$

of absorbed ai of applied ai

$\begin{array}{lll}\text { glyphosate }(1.08 \mathrm{~kg} / 2001) & 74 & 61 \\ + \text { Browndown } 0.25 \% & 74 & 69 \\ + \text { Browndown } 0.5 \% & 78 & 74\end{array}$

There were no significant differences between treatments (LSD; $\mathrm{P}=0.05$ )

Retention of glyphosate spray was $50 \%$ of maximum possible deposition on all leaf surfaces (Table 3). Addition of Pulse and the higher concentration of Browndown had no effect on the volume of spray retained, while the lower Browndown concentration decreased retention relative to the non-adjuvant spray (by $8 \%$ ).

At 2 DAT, potted ryegrass treated with glyphosate+Browndown began to brownout, and these symptoms developed to affect $95 \%$ of the foliage by harvest at three weeks. Symptoms were slightly more severe at the higher concentration $(0.5 \%)$. Ryegrass sprayed with glyphosate and with glyphosate+Pulse developed mild phytotoxic symptoms after one week, which increased in severity to include $90 \%$ of the foliage at harvest. Spray efficacy of a sub-lethal dose of glyphosate was increased only slightly with adjuvants (Table 3 ) and only Browndown $(0.25 \%)$ significantly improved on the herbicide alone. There were no differences between adjuvant treatments. 
TABLE 3: Retention and efficacy (21 DAT) of glyphosate sprays on potted ryegrass.

\begin{tabular}{lcc}
\hline Treatment & $\begin{array}{c}\text { Retention } \\
(\%)\end{array}$ & $\begin{array}{c}\text { Efficacy } \\
(\% \text { reduction in DW) }\end{array}$ \\
\hline glyphosate (1.08 kg/200 litres) & $50 \mathrm{a}$ & $68 \mathrm{~b}$ \\
+ Pulse 0.1\% & $53 \mathrm{a}$ & $71 \mathrm{ab}$ \\
+ Browndown $0.25 \%$ & $42 \mathrm{~b}$ & $77 \mathrm{a}$ \\
+ Browndown $0.5 \%$ & $48 \mathrm{a}$ & $76 \mathrm{ab}$ \\
\hline
\end{tabular}

Means within columns sharing common postscripts are not significantly different $(\mathrm{LSD} ; \mathrm{P}=0.05)$

In the field, the glyphosate+Browndown treatment browned-out faster than the glyphosate+ Pulse treatment ( 80 and $60 \%$ brown-out at 7 DAT, respectively), but there were no differences between them by 21 DAT (98\% brown-out). By 35 DAT both adjuvant treatments were showing signs of recovery, with green tillers appearing from the ryegrass crowns. At both 35 and 56 DAT there were no differences between Browndown and Pulse in their ability to suppress new growth and to overcome the seasonal tolerance of ryegrass to glyphosate (Table 4).

TABLE 4: Ryegrass frequency (plants $/ \mathrm{m}^{2}$ ) after field application of glyphosate+ adjuvant.

\begin{tabular}{lccc}
\hline Treatment & Pre-spray & $35 \mathrm{DAT}$ & $56 \mathrm{DAT}$ \\
\hline Water control & 102 & $102 \mathrm{a}$ & $108 \mathrm{a}$ \\
glyphosate+Pulse $0.1 \%$ & 90.5 & $2.8 \mathrm{~b}$ & $5.8 \mathrm{~b}$ \\
glyphosate+Browndown $0.25 \%$ & 91.8 & $2.8 \mathrm{~b}$ & $5.5 \mathrm{~b}$ \\
\hline
\end{tabular}

Means within columns sharing common postscripts are not significantly different (LSD; $\mathrm{P}=0.05)$

\section{ACKNOWLEDGEMENTS}

Thanks to Kevin Steele for technical assistance and Elliott Chemicals Ltd for technical information and support.

\section{REFERENCES}

Bishop, N.G. and Field, R.J., 1987. Controlling perennial ryegrass with glyphosate in spring. Proc. 40th N.Z. Weed and Pest Control Conf.: 194-198.

Field, R.J. and Bishop, N.G., 1988. Promotion of stomatal infiltration of glyphosate by an organosilicone surfactant reduces the critical rainfall period.Pestic. Sci. 24 : $55-62$.

Field, R.J., Buick, R.D and Dastgheib, F., 1995. Analysis of the relationship between surfactant addition and the translocation of herbicide active ingredient. Proc. 4th Int. Symp. on Adjuvants for Agrochemicals, NZ FRI Bulletin No. 193: 201-206.

Foot, D. (Ed) 1997. Browndown Adjuvant. Pp 1. Additives Product Listings In: New Zealand Agrichemical Manual; Wham Chemsafe Ltd, Wellington, New Zealand.

Gaskin, R.E., 1995. Effect of organosilicone surfactants on the foliar uptake of herbicides; Stomatal infiltration versus cuticular penetration. Proc. 4th Int. Symp. on Adjuvants for Agrochemicals, NZ FRI Bulletin No. 193: 243-248.

Gaskin, R.E. and Murray, B., 1988. Surfactant effects on activity of glyphosate and haloxyfop in pampas grass. Proc. 41st N.Z. Weed and Pest Control Conf:: 153155.

Gaskin, R.E. and Zabkiewicz, J.A., 1988. Effect of Silwet L-77 on uptake and translocation of metsulfuron in gorse. Proc. 41st N.Z. Weed and Pest Control Conf: : 149-152. 